\title{
Interpersonal Relationship and Personality Development on the Main Character in R.J Palacio's Wonder Novel
}

\author{
Eka Margianti Sagimin ${ }^{1}$ and Linda Nurarsita Damayanti ${ }^{2}$ \\ English Department- Universitas Pamulang ${ }^{1,2}$ \\ Email:ekamargy@yahoo.com
}

\section{E-ISSN : 2579-4574}

P-ISSN : 2549-7359

\begin{abstract}
This study aims to find the personality development of the main character in the Wonder novel, August Pullman. The objective of this study is to show how August's interpersonal relationship depicted in the novel and influenced his personality development. The theory of Interpersonal Relationship from Harry S. Sullivan is used to analyze how August's social interaction with others affect his personality development. This study found that someone's personality development can be seen through the relationship between individual and others. In addition, to find out the factors of personality development, this study uses Elizabeth B. Hurlock's theory of Personality Development. Some factors which are responsible for someone's change are changes in environment, changes in social pressure and changes in self-concept. Based on the analysis, August's personality in Wonder novel is described as an unconfident, weak, and has limit social interaction developed into confident, brave, and independent kid.
\end{abstract}

Keywords: personality, personality development, interpersonal relationship, social pressure, self-concept

\section{https://ojs.unm.ac.id/eralingua}

\section{INTRODUCTION}

Personality of human is a complex thing to be studied. Every human being has different personality. Personality can be said as the range of different styles of thinking, feeling and acting. People are different not only in terms of their physical traits, but also in mental and behavior traits. According to Oldham and Morris (1995), personality is people organizing principle. It represents the orderly arrangement of all people attributes, thoughts, feeling, behavior, and coping mechanism. Based on what Oldham and Morris explained, it shows that every human has different personality because the way people think and behave is different. In some ways human are the same and has the same human nature. Yet, in other ways humans are completely different and unique. For example, some people are known as talkative and outgoing while others are noticeably quiet and reserved. Personality is people different ways of being human. For it is different, personality stated as an identity of human.

Regarding human's personality Allport in Ewen (2010) stated that, personality is composition of dynamic psychophysical systems within the individual, 
which determines the unique adjustment to the environment. It clearly stated that psychophysical includes attitudes, emotional states, beliefs and values. Meanwhile, according to Santrock (2005), he defines personality itself as enduring, distinctive thoughts, emotion, and behavior that characterize an individual to the world. Those opinions show that personality is how human behave, for it comes from their emotional states, their belief and thought. Kinds of individual's personalities can be seen through his behavior in facing significant situation Moreover, Personality is changing, as defined by Pikunas (1961) there are many influence personality developments. They are biological or genetic factors, the way individual thinks, the way human beings behave toward each other and experiences in real life. Kenberg \& Caligor (2005) stated the changing of personality refer to the dynamic integration of the totality of a person's subjective experience and behavior patterns, including both conscious, concrete, and habitual behavior. According to Kenberg in his journal (2016), personality is relatively stable over the time. Meanwhile, it is also subject to change across the entire lifespan. It could be mean that personality changes can still occur depending of new life experiences. For example, for people who experience a trauma, significant life changing event, even the kind of social role we take on, can change our personality. The first-time parents or person who gets started in the new organization may find themselves becoming more aware with their responsibilities, so they will change how they think, feel, and behave in general. It also could happen with people in the new relationship, they became aware of their partner's well-being as their perspective of the world changes. It happens in our life changes, so does our personality.

According to Sullivan in Morgan (2004), he explains that personality is a hypothetical entity which cannot be isolated from interpersonal situation and, indeed, interpersonal behavior is all that is observable about personality. The rest, he suggests that it is futile and fruitless to speak of a person's personality outside the social interaction. Based on Sullivan's theory, Mihailovic \& Lojic (2003) explain in their journal that interpersonal relation largely influences one's personality development. This statement also strengthen with Karen Horay's theory that focused on the social cultural factors that influence human mental health, behavior, and interpersonal relationship. Sullivan and Horay believe that interpersonal relations influenced the development of the personality. For example, a child raised by a parent who smokes, most likely the child will imitate the smoking behavior of his parents, indirectly interpersonal relationship between the child and parents affect child's personality development.

Completing the Sullivan's theory, Hurlock (1974) states there are two factors that influence changes in one's personality; internal and external factors. The internal factor comes from the person him/herself, such as changing of age which influences the individual's personality. The external factor comes from the outside of the person such as other people's attitude and treatment toward him/her. External factor which Hurlock emphasized quite similar with the theory of interpersonal relationship from Sullivan. Besides the internal and external factors, Hurlock (1974) also mention some several conditions that responsible for the change of someone's personality development. The easiest way to see the changing 
of human's personality development is from literature. Literature comes from human mind and one of literary work that have an issue from a real life is a novel. Hudson (1958) states "literature itself is on account of its deep and lasting human significance". It clearly shows that literature seems like a record of human life. One of novel that shows the changing in personality of the main character is Wonder by R.J Palacio.

Wonder is a novel by R.J Palacio, which tells about a ten-year-old boy living in New York City named August and was born with a facial deformity that has made it difficult for his social life. He lived with his parents and his older Sister. August has been homeschooled up until the fifth grade, and his parents decided to send him to go to a real school. While August starting 5 th grade in the real school, he had experienced a lot of rejection from his classmate because of his extraordinary look but August gets a lot of supports from his family. His family plays a vital role in August's personality development. In the end of the story, August can change his personality and build his self-esteem.

The reason why the writer analyzed the interpersonal relationship between August and another character in Wonder novel is that this will help the readers to understand more about personality development of the main character during the story. It is strengthened by Bennet and Royle (2004) by saying that trough power of identification character in the novel can become part of how the readers visualize themselves; a part of who they are (P.60). Also, there are a lot of value that the reader can take from this novel such as friendship, teamwork, sincerity, honesty, and struggle. By using psychological theory, the writer takes initiative to analyze the personality development of the character entitled "Interpersonal Relationship and Personality Development of the Main Character (August) in R.J Palacio's Wonder Novel". The method used is descriptive qualitative since the writer analyzed and described the data into form of essay.

\section{RESULT AND DISCUSSION}

The analysis of the data used the psychoanalysis concept in order to find the personality development in Wonder Novel. Wonder reflects the development of the personality of the main character. As it is titled as Wonder, the personality development of the main character left the people around him amazed, the main character changed into a wonderful person.

\section{Interpersonal Relationship}

The interpersonal relationship theory by Harry Stack Sullivan is used to find out the personality development occurs in R.J Palacio's novel Wonder. Sullivan as stated in Mihailovic \& Logic (2003) that interpersonal relations significantly influence the process of personality formation and on the development of its important features. Sullivan in Feist \& Feist (2008) distinguish that the process of developing an identity and personality is caused by one's relationship among others.

"You don't have to do anything you don't want to do," Dad said, coming over and lifting me out of Mom's lap. He carried me over to sit on his lap on the other side of the sofa. "We won't make you do anything you don't want to do."(Palacio: 9) 
This quotation shows an interpersonal relationship between August and his dad. The way he "lifting" August out of his mother and "carried" him to sit on his lap indicates that August is loved by his parents. The way his father let August decide shows that their relationship slowly influence August's personality. His dad decided to let August choose, teach him to choose what better for his life, but still in his parents' eyes. On the other hand, his dad's statements implicit that he is worried about what will August face once he enters school. This could influence August's personality that he is afraid and being a spoiled kid because his parents also do what he asks.

Besides the Interpersonal Relationship that August experienced in his life, Personality Development of August in Wonder novel can be seen through the situation and event from August's experience in the story. When the environment changes and not rateable with the individual's value and belief, thus the individual must change their personality to meet the balance of the environment. The changes or development of August's personality in Wonder novel can be analyzed with Hurlock theory. In the theory of Personality Development, Hurlock defines some conditions that responsible for the changes or development of the individual. In Wonder novel, there are three conditions in August's personality changes. They are Changes in Environment, Changes in Social Pressure and Changes in Self-concept.

\section{Condition Responsible for Personality Changes}

\section{a. Changes in Environment}

One of the conditions that take effect to August's personality is his environment. According to Hurlock (1974) to improve one's personality, the environment must do several things, one of which is the environment must help the person to see himself more realistically. Changes of August's personality can be seen in quotation, "But I know ordinary kids don't make other ordinary kids run away screaming in playground"(Palacio: 3). The quotation shows that August knows he is not an ordinary kid. In the quotation, it is also clear that Environment taught August indirectly that he must realize who he really is. With the limitations he has, August realizes that he can't be an ordinary kid like others, because ordinary kids don't get stared at where ever they go. This made August not have much confidence in his life because environment made him understand that he was not an ordinary kid.

\section{b. Changes in Social Pressure}

Hurlock (1974) states that Social Pressure a person experience will force them to change the way they think, habit, value and belief or can be said as personality so a person can be accepted in society.

\footnotetext{
"So, are you into Star Wars, August?"

"I guess." I nodded, not looking up because what I really wanted was to just slide under the desk. (Palacio: 43).
}

The quotation above shows that August is not too confidence talking in public. This event happens when his teacher, Ms. Petosa asks everyone in class to introduce themselves in front of class. August's turn comes and he begins to talk. Less social interaction that August faced or experienced and his facial deformity 
make August not confident in every class activity or getting involved in public activities. Even though August does not like it, he does not have a change to refuse it. Social pressure that his teacher gave to him taught August how to behave in front of other people. While his teacher asks him to walk in front of class and introduce himself, he did it even though he does not feel confident and afraid because every eye on him. Social pressure that he got teaches August to be more confident and give him a chance to put himself in society, so he can be accepted in society.

\section{c. Changes in Self-concept}

Another condition which is responsible for the changing in one's personality is change in self-concept. Self-concept is said as every image and perspective we see about ourselves. Hurlock emphasizes in her theory that self-concept is everything you know about yourself, everything you believe in, and what has happened in your life is captured in the mental drive of your personality, that is, in your self-concept. At the beginning of the story, August describe as a kid who is not confident with his appearance, "I won't describe what I look like. Whatever you're thinking, it's probably worse" (Palacio: 3). This quotation depicted that August describe his appearance as bad as possible.

August self-concept began to change when he had friends who always sat with him in a class named Jack. Jack is the only person who wants to sit with August. Their friendship helped August to change his perspective of how he judged himself. August realize that his "face would always surprise some unsuspecting kid who maybe hadn't heard about" (Palacio: 61). His school life and his social interaction influence the change in his self-concept. He begins to accept other's act towards him and he started to accept who he really is. August's interaction with Jack had a major impact on the change in August's self-concept. Jack is helping August to establish his confidence as in quotation "he noticed kids staring at me, but he pretended not to notice." (Palacio: 63). Jack also sometimes makes jokes about people who are shocked and even scared when they meet August. August's introspection process is helped with his interaction with Jack that made August's self-concept change. Those changes also affected the personality development of August.

\section{CONCLUSION}

Based on the analysis, the development of the main character, August's personality appears through his relationship with her family including his parents, sisters; his teacher, and his friends. For example, August is kid with facial deformity and has small social interaction and also known as week, scared, lack of confident and overprotective by his mother developed to be a brave and confident kid and inspires other people around him. In addition, child's identity development will not be developed without conditions that are responsible for the development or can be said as a factor. In this novel there are some conditions which are responsible to the development of August's personality based on Elizabeth B. Hurlock theory, they are changes in environment, changes in social pressure and changes in self-concept. This novel depicted how the three conditions affect August's personality development. August experienced changing in his environment from home schooled child into a real student in public school, while in school he experienced a 
lot of social pressures from his friends. Changes in his environment and his social pressure also have a connection with his self-concept. In this novel, August also experienced the changes in his self-concept. In the analysis, it has been proved that if one experienced changes in their environment, social pressure and self-concept, the entire personality of that individual will change or develop.

\section{REFERENCES}

Bennet. A \& Royle. N (2004) Introduction to Literature Criticism and Theory. Great Britain: British Library Catalogue.inc

Creswell. J. W (2003) Educational Research Methodology. Boston: Pearson Education.

Ewen, R. B, (2010) An Introduction to Theories of Personality. New York: Taylor and Francis Group, LLC.

Feist, J., \& Feist, G. J. (2008). Theories of Personality (7th ed.). New York: McGrawHill.

Forster, E. M. (1956). Aspects of the novel. Harmondsworth: Penguin Books.

Hurlock, B. Elizabeth, 1974. Personality Development. New Delhi: Tata Mc Graw Hill.

Naisaban. (2004) Para Psikolog Terkemuka Dunia: pokok Pikiran, riwayat hidup dan karya. Jakarta: Gramedia

Kenney, W. (1966). How to Analyze Fiction. New York : Monarch Press. Print.

Kernberg, O. (2016) Journal of Personality Disorder, Volum 30 (2), 145-156 : The Gullford Press.

Kernberg, O. F., \& Caligor, E. (2005). A Psychoanalytic Theory of Personality Disorder. New York: The Guilford Press.

Mangold, R. F. (2012). Richard F. Mangold. Retrieved July, 9 2018, from Illinois Valley Community College: https://www.ivcc.edu/facultywebpages/mangold.aspx

Marcia, J. E., Waterman, A. S., Matteson, D. R., Archer, S. L., \& Orlofsky, J. L. (1993). Ego Identity: A Handbook for Psychosocial Research. New York: Springer-Verlag New York Inc.

Mihailovic, D. \& Lojic, R. (2003) Interaction of Personality and Interpersonal Relations. Tour.hosp.manag, 9(2),97-106.

Monte, F. (1877) Beneath the Mask. New York: Praegar Publishers, Print.

Nordelman, P \& Reimer, M. (2003). The pleasures of children's literature. Boston: Allyn and Bacon.

Oldham, J. M., \& Morris, L. B. (1995). New Personality Self Portrait. New York: Bantam Book

Pallacio, R.J (2012). Wonder. Great Britain: Penguin Random House.

Richard Barsam, (2007). Looking at Movies: an Introduction to Film, 2nd ed, New York: W. W. Norton \& Company.

Reeve, C. (1785) Progress of Romance. Great Britain: Frederic Warne.

Santrok, J. W (2005), Psychology Updated Seventh Edition. New York: McGraw Hill.

Sullivan, H. S, edited by Perry, H. S \& Gawel, M. (1953) The Interpersonal Theory of Psychiatry . Great Britain: Tavistock Publication Limited. 